\title{
EHMTI-0096. Efficacy of sumatriptan: assessment of a possible biomarker
}

\author{
K Ibrahimi* ${ }^{*}$ AH Danser, AH van den Meiracker, A MaassenVanDenBrink \\ From 4th European Headache and Migraine Trust International Congress: EHMTIC 2014 \\ Copenhagen, Denmark. 18-21 September 2014
}

\section{Introduction}

Sumatriptan is a frequently applied anti-migraine treatment, yet $\approx 20-30 \%$ migraineurs are nonresponders. TRPV1 channels on trigeminal nerve endings release CGRP during migraine attacks, while, supposedly, stimulation of the presynaptic $5-\mathrm{HT}(1 \mathrm{~B}) / 1 \mathrm{D}$ receptor by sumatriptan inhibits this release. Capsaicin (CAP) stimulates TRPV1 channels, causing CGRP-dependent vasodilatation, whereas electrical stimulation (ES) induces vasodilation without direct TRPV1 activation.

\section{Aim}

To assess a possible biomarker for the efficacy of sumatriptan.

\section{Methods}

We investigated the effect of sumatriptan on the rise of dermal blood flow (DBF) of the forehead skin (innervated by the trigeminal nerve) by CAP application $(0.6 \mathrm{mg} / \mathrm{ml})$ and ES (0.2-1.0 $\mathrm{mA}$ ) before and after subcutaneous placebo and sumatriptan in a randomized, double-blind, placebo controlled cross-over study, including healthy male $(\mathrm{n}=11$, age \pm SD: $29 \pm 8 \mathrm{yrs})$ and female $(\mathrm{n}=11,32 \pm$ 7 yrs) subjects.

\section{Results}

DBF responses to CAP (mean \pm SEM: $313 \pm 16$ A.U.) were significantly attenuated after sumatriptan (mean decrease DBF: $82 \pm 18$ A.U., $\mathrm{p}<0.001$ ) but not after placebo (mean decrease DBF: $21 \pm 12$ A.U., $\mathrm{p}=0.1026$ ), whereas DBF responses to ES were not affected by sumatriptan or placebo. Sumatriptan, but not placebo, increased blood pressure by $6 \pm 2 / 11 \pm 2 \mathrm{mmHg}, \mathrm{p}<$ 0.001 . In $23 \%$ of the subjects, sumatriptan did not attenuate the DBF response.

Department of Internal Medicine, Erasmus MC, Rotterdam, Netherlands

\section{Conclusions}

Sumatriptan may inhibit the release of CGRP via the stimulation of the presynaptic 5-HT(1B)/1D receptor and/or by a direct effect on TRPV1 channels. ES appears to be a nonspecific stimulus, most likely releasing other neuropeptides besides CGRP. Future studies should indicate whether nonresponse in our model correlates with clinical nonresponse to sumatriptan.

No conflict of interest.

Published: 18 September 2014

doi:10.1186/1129-2377-15-S1-G16

Cite this article as: Ibrahimi et al:: EHMTI-0096. Efficacy of sumatriptan: assessment of a possible biomarker. The Journal of Headache and Pain 2014 15(Suppl 1):G16.

\section{SpringerOpen $^{\circ}$}

(c) 2014 Ibrahimi et al; licensee Springer. This is an Open Access article distributed under the terms of the Creative Commons Attribution License (http://creativecommons.org/licenses/by/2.0), which permits unrestricted use, distribution, and reproduction in any medium, provided the original work is properly cited.
Submit your manuscript to a SpringerOpen ${ }^{\circ}$ journal and benefit from:

- Convenient online submission

- Rigorous peer review

- Immediate publication on acceptance

- Open access: articles freely available online

- High visibility within the field

- Retaining the copyright to your article

Submit your next manuscript at $>$ springeropen.com 